\title{
Оксана Кирилова
}

Дніпровський національний університет імені Олеся Гончара пр. Гагаріна, 72, Дніпро, 49005, Україна

(1) https://orcid.org/0000-0001-5393-0138

kyrylova_o@fszmk.dnulive.dp.ua

\section{НАУКОВА ТА НАУКОВО-ПОПУЛЯРНА ЖУРНАЛІСТИКА: СКЛАДНОЩІ ДЕФІНІЦІЇ ПОНЯТЬ І ТИПОЛОГІЗАЦІЇ МЕДІА}

\begin{abstract}
Актуальність статті полягає в потребі наукової диференціації двох суміжних категорій сучасної комунікативістики: «наукова журналістика» (science journalism) та «науковопопулярна журналістика» (popular science journalism). У вітчизняному дискурсі не існує сталого підходу до цього питання, а чинні нормативні документи змушують редакції визначати вид діяльності не за специфікою медіа, а за переліком, наявним, наприклад, у ДСТУ. Об'єктом дослідження стали світові та вітчизняні ресурси, які спеціалізуються на науковій тематиці: Cosmos, Popular Science, Discover, Scientific American, «Куншт», «Спільне», «Світогляд», «Вселенная, пространство, время», Science Ukraine, Alpha Centauri, «Наука и техника», «Країна знань», «Вічний мандрівник», «Локальна історія», «Історія. Новий погляд», «Маловідома історія: далеке і близьке». При цьому аналізувалися як діджитальні практики (вебресурси), так і традиційні паперові ЗМІ (журнали). Предмет вивчення - особливості дефініції наукової та науково-популярної журналістики і складності типологізації відповідних медіа. Основним методом дослідження став компаративний аналіз, підкріплений дискурс-аналізом. Метод дав змогу, по-перше, порівняти наявні наукові погляди на категорії «наукова журналістика» та «науково-популярна журналістика» і виокремити головні риси кожної; по-друге, здійснити аналіз провідних світових ресурсів, які спеціалізуються на науковій журналістиці, та провести паралелі з українськими медіа такого типу.

Результатом дослідження $є$ типологічна диференціація сучасних медіа. Основою дослідження стала гіпотеза, що визначальними в плані диференціації медіа як наукових і науково-популярних є характеристика аудиторії та функціональна специфіка ресурсу. Відповідно до неї ті медіа, які орієнтуються на підготовленого користувача, зосереджуються на останніх досягненнях науки й техніки та обмежено використовують онлайнові можливості, майже не вдаючись до прийомів едьютейнменту та саєнстейнменту, ми віднесли до каналів наукової журналістики. Ресурси ж, які об’єднують спрямування на масового користувача, акцент на навчальний складник та орієнтація на популярні навколонаукові теми, що мають пролонговану потенційну актуальність, ми вважаємо науковопопулярними. 3 урахуванням аудиторного і функціонального факторів у статті до наукової журналістики відносимо проєкти «Куншт», «Спільне», «Світогляд», «Вселенная, пространство, время», Science Ukraine, Alpha Centauri, «Наука и техника», «Країна знань», а «Вічний мандрівник», «Локальна історія», «Історія. Новий погляд», «Маловідома історія: далеке і близьке» - до науково-популярної.

Ключові слова: наукова журналістика; науково-популярна журналістика; науковий медіадискурс.
\end{abstract}

Вступ. У 2009 р. лікар і науковий блогер, постійний ведучий тижневої наукової колонки для The Guardian Бен Голдакр так схарактеризував сучасну наукову журналістику:

Люди, які керують ЗМI, - здебільшого випускники гуманітарних спеціальностей, які мало тямлять на науці, які носять невігластво як почесний знак. Потай, глибоко в душі, можливо, вони обурюються тим, що відмовили собі в доступі до найважливіших подій в історії західної думки за останні 200 років; однак усі медіа, що висвітлюють науку, піддаються критиці: обираючи історії та спосіб їх подання, ЗМІ створюють пародію на науку. Згідно з цим шаблоном наука зображується як безпідставні, незрозумілі, дидактичні твердження вчених, які самі по собі $\epsilon$ в соціальному плані впливовими, деспотичними, невиборними авторитетними фігурами. Вони відірвані від реальності, виконують роботу, яка $€$ або небезпечною, або шкідливою, але в будь-якому разі все в науці $є$ плинним, суперечливим, мінливим i, що найсмішніше, «важко зрозумілим». <...> Причина такої ситуації пов'язана із журналістським припущенням, що аудиторія не зможе зрозуміти «шматок науки». Це означає, що історії мають ефективно «приглушувати», і це рівнозначно відчайдушній спробі спокусити та залучити невігласів, яких наука й так не цікавить. <..> Здебільшого медіа постійно так видовищно провалюють науку через те, що редактори цинічно віддають перевагу «дурним історіям», які продаються. (Allan, 2011, p. 771) 
Ми свідомо розпочинаємо аналіз специфіки наукової та науково-популярної журналістики із цієї провокативної цитати, розуміючи, що вона в одному таборі науковців викличе жваву емоційну підтримку, а в іншому - таке ж жваве емоційне обурення. Поділ на «фізиків» і «ліриків» у світовій науковій спільноті з розвитком та розширенням загального дискурсу не лише нікуди не подівся, а ще й загострився як поточною ситуацією (згадаймо жваву дискусію в українському полі щодо публікацій наукових статей в індексованих журналах), так і медіатизацією наукового простору, яка вивела протистояння двох таборів у середовище масової культури, наприклад постійне дистанціювання головних героїв серіалу «Теорія великого вибуху», які відносять себе до «фізиків», від іншої, зокрема гуманітарної сфери, яку вважають недонаукою. Ми не прагнемо розставити пріоритети в цій суперечці, але вважаємо точку зору Голдакра, м'яко кажучи, сумнівною з огляду хоча б на той факт, що всі наукові журнали, попри їхню спеціалізацію, мають ISSN, а отже, належать до засобів масової інформації, масмедіа, редакторів яких так суворо критикує блогер. Згадана точка зору використана для того, щоб одразу визначитися з тим дискурсом, який потрапив у поле нашого аналізу.

Методи. Основним методом дослідження став компаративний аналіз, який, підкріплений дискурс-аналізом, дав можливість, по-перше, порівняти наявні наукові погляди на категорії «наукова журналістика» та «науково-популярна журналістика» й виокремити головні риси кожної; подруге, за допомогою цих методів були проаналізовані провідні світові ресурси, які спеціалізуються на науковій журналістиці, і проведені паралелі з українськими медіа такого типу.

Для цього дослідження висувалася гіпотеза, що визначальними в плані диференціації медіа як наукових і науково-популярних $€$ характеристика аудиторії та функціональна специфіка ресурсу. Відповідно до неї ті медіа, які орієнтуються на підготовленого користувача, зосереджуються на останніх досягненнях науки й техніки та обмежено використовують онлайнові можливості, майже не вдаючись до прийомів едьютейнменту та саєнстейнменту, ми віднесли до каналів наукової журналістики. Ресурси ж, які об'єднують спрямування на масового користувача, акцент на навчальну складову й орієнтація на популярні навколонаукові теми, які мають пролонговану потенційну актуальність, ми вважаємо науковопопулярними.

Об'єктом дослідження стали світові та вітчизняні ресурси, які спеціалізуються на науковій тематиці: Cosmos, Popular Science, Discover, Scientific American, «Куншт», «Спільне», «Світогляд», «Вселенная, пространство, время», Science Ukraine, Alpha Centauri, «Наука и техника», «Країна знань», «Вічний мандрівник», «Локальна історія», «Історія. Новий погляд», «Маловідома історія: далеке і близьке». При цьому аналізувались і діджитальні практики (вебресурси), і традиційні паперові 3МI (журнали).

Аналіз останніх досліджень та публікацій. Сучасна наукова думка не пропонує чіткої диференціації між науковою та науково-популярною журналістикою. С. Суворова вважає:

Наукові видання, наукова періодика - це інструмент і результат наукової діяльності, який дає змогу глибоко і всебічно досліджувати й вирішувати найрізноманітніші наукові проблеми, важливі для розвитку науки, але не підлягає оперативному включенню в соціальний контекст. <...> Наукові публікації, публікації в наукових журналах, науковій періодиці а саме їх передусім мають на увазі, коли мова йде про «наукову журналістику», - не розраховані на масового читача. (2009, с. 15-16)

Водночас Т. Пічугіна розуміє під науковою журналістикою «область журналістики, яка займається наукою. Таким чином, зміни всередині науки, зміна позиції науки в суспільстві, ускладнення зв'язків з організаціями та владними структурами відбиваються так чи інакше в науковій журналістиці» (Пичугина, 2006). Думка С. Муравіцької така:

Наукова журналістика, методом спрощення складного для розуміння широким читацьким масам «сухого», обтяженого термінологією, наукового тексту, так би мовити - його перекладом, доносила новини й події сфери науки до громадськості. <..> Термін «наукова журналістика» $€$ активно вживаним і має на увазі діяльність науково-популярних 3MI, які висвітлюють питання розвитку та досягнень науки. (2016, с. 56)

0. Фарберович акцентує той факт, що «раніше науковій журналістиці відводилася роль популяризатора науково-технічного сектора 3 метою роз'яснення (як перекладача між ученими та аудиторією), але з часом вона виступає як засіб залучення в професійну науку молодого покоління» (2016, с. 99).

Західний науковий загал вважає класичною роботу Д. Нелкін «Продаж науки: як преса висвітлює науку і техніку» (1995) (понад 2 тис. посилань y Google Scholar). У цьому дослідженні визначені три головні функції наукової журналістики:

1) бути в курсі наукових досягнень;

2) оцінювати доцільність наукових досліджень;

3) робити вибір, пов'язаний з усвідомленням особистих ризиків (Nelkin, 1995).

Таким чином громадськість, поінформована науковою журналістикою, повинна мати більше можливостей для того, щоб приймати рішення, зіштовхуючись із суперницькими науковими аргументами щодо безпеки, здоров'я, довкілля тощо. Виходячи з цього, Д. Секко, Е. Аменд і Т. Фрайдей 
пропонують розглядати чотири моделі наукової журналістики (Secko et al., 2013):

1. Модель наукової грамотності - ставить на меті «переклад» наукової інформації, декодування текстів таким чином, щоб вони стали зрозумілими більшості; надання відомостей, необхідних для прийняття рішень у повсякденному житті. Педагогічно орієнтована модель, із фокусом на підвищенні наукової грамотності або на рівні розуміння громадськістю науки, та передбачає лінійну структуру передачі знань «згори вниз» від учених журналістам, які «перекладають» наукову та дослідницьку інформацію в зрозумілі новини.

2. Контекстна модель - розглядає наукову інформацію в їі конкретних контекстах, пов'язаних з аудиторією, а отже, подає ії ефективніше навіть за умови зберігання алгоритму передачі знань «згори вниз».

3. Модель непрофесійної експертизи - прирівнює місцеві знання до наукових. Вона руйнує низхідну концепцію «згори вниз» щодо відносин між наукою та суспільством, залучаючи у свій загал знання та проблеми / експертну оцінку певних верств населення. Знання оцінюються самі по собі й перевіряються за допомогою інших соціальних систем. Наука розуміється як обмежена та невизначена, а отже, потребує зовнішньої «експертизи».

4. Модель громадської участі - намагається зробити науковий процес більш інтерактивним, заохочує публічні дебати навколо наукових питань. Наукова журналістика менше фокусується на навчанні людей або заповненні прогалин у знаннях, а сприяє активному залученню зацікавлених сторін до процесу наукового спілкування для покращення довіри між цими групами. Модель участі громадськості відмовляється від лінійної структури передачі знань, наголошуючи на демократизації й участі громадськості в науковому процесі, особливо стосовно питань політики. 3 погляду журналістики модель участі громадськості більше зосереджується на процесах, що стоять за наукою, включає безліч точок зору зацікавлених сторін і спрямована на залучення аудиторії до плюралістичних дискусій.

Розуміючи, що третя й четверта моделі містять потенціал для функціонування в просторі масової комунікації, можна припустити, що саме вони $є$ ефективними при формуванні науковопопулярного дискурсу. С. Суворова тлумачить науково-популярні журналістські матеріали як такі, що

публікуються як у науково-популярних журналах, так і в універсальних суспільно-політичних, якісних, масових друкованих 3МІ. Науково-популярна тематика відображається і в телерадіопередачах, інтернет-3MI, на стрічках інформаційних агентств. Тексти науковопопулярної журналістики призначені для масової аудиторії, викладаються загальнодоступною мовою і $є$ адаптованим для каналів масової комунікації оперативним знанням про продукти науки й тих, хто їх створює. (2009, с. 17)

М. Літке апелює до лексичної структури терміна «науково-популярний», говорячи про

подібні засоби масової інформації, які мають своїм предметом науку (наукові дослідження, їх результати), а їх основне завдання - популяризація, дохідливе пояснення складної наукової інформації читачеві-неспеціалісту. При цьому очевидно, що поняття «науково-популярної» журналістики значно вужче за поняття «пізнавальної» або «науково-пізнавальної» журналістики, де об'єктом можуть бути не тільки результати наукових досліджень, а й реальність як така, взята безпосередньо (у зв'язку з цим уся журналістська практика може бути охарактеризована як «пізнавальна»). (2014, с. 60)

Дослідниця пропонує ресурси, які, «звертаючись до реальності у всьому їі різноманітті, виходять із принципів наукового пізнання і спираються на результати наук як правдиві, адекватні завданням об'єктивного опису і пояснення світу на всіх його рівнях, у всій її своєрідності зв'язків і відносин» $(2014$, с. 60$)$, відносити до науковопізнавальних. Ті ж медіа, чий предмет обмежується результатами наук, а інтенція - популяризацією наукових результатів, становлять підтип науково-популярних видань у розділі науковопізнавальної журналістики. Підхід М. Літке не можна назвати традиційним, але він має право на існування. О. Фарберович уважає: «якщо наукова журналістика прагне інформувати інтелектуальну аудиторію і просувати наукові досягнення, то науково-популярна навчає та розважає масового читача» (2016, р. 102).

Досить детальний аналіз науково-популярного медіадискурсу представлений у роботах українських (В. Кисіль (2020), М. Бутиріна (2020), Д. Шевченко та Н. Ковтун (2019), М. Іваницька та М. Кіца (2018), Д. Філоненко (2017, 2014), Н. Бороздих (2018, 2017) та ін.) та закордонних авторів (К. Молек-Козаковська $(2017,2016)$, Т. Тутен і Л. Темесвари (2013) тощо). Науково-популярну журналістику вивчали С. Зайцева (2020), С. Данвуді $(2020,2014)$, Й. Барел-Бен Давид, Е. С. Гарті, А. Барам-Цабарі (2020), О. Гарматій (2019), В. Кисіль (2019), В. Бурдега і Т. Слотюк (2018) та ін.

Результати. Описуючи історію наукової журналістики у Великобританії, М. Буккі та Б. Тренч (2014) говорять про поступову заміну науковців, які співпрацювали із журналами й газетами, на журналістів (Bucchi \& Trench, 2014, p. 27-28). Учені епохи просвітництва до кінця XVIII ст. прагнули поширювати наукові знання, інтегруючи їх у повсякденний світ звичайних людей. Саме такі завдання ставили перед собою Теофаст Ренодо, започатковуючи 1665 р. в Парижі 
науково-літературний Journal des savants, та Лондонське королівське товариство, яке тоді ж започаткувало в Лондоні Philosophical Transactions of the Royal Society. Але вже у XIX ст. невпинний розвиток спеціалізованих знань почав створювати прірву між представниками науки та суспільством. Наприкінці XIX ст. 3 носіїв і поширювачів просвітницьких ідей учені перетворилися на недосяжних професійних експертів, які володіли ексклюзивними знаннями, що мали вже не лише науковий, а й комерційний потенціал. У міру того, як учені віддалялися від популяризації знань, процес створення науково-популярних текстів усе більше перекладався на журналістів (Bucchi \& Trench, 2014, p. 28). Така ж тенденція спостерігалася і в США. Створені у XIX ст. журнали Scientific American (1845) та Popular Science Monthly (1872) друкували науково-популярні статті, які залюбки передруковували американські газети. Популярністю користувалися наукові лекції, думки вчених про природничі явища, наприклад метеоритні дощі. I якщо до кінця XIX ст. співпраця вчених і журналістів була обопільною, то вже на початку XX ст. науковці почали дистанціюватися від участі у творенні мас-медійного простору. Вони створили власну мову, власні моделі комунікації, а великі наукові товариства навіть почали карати вчених за надмірну відкритість та участь у популяризаторських проєктах. Через загрозу руйнування кар'єри науковці облишили цю активність, передавши ії журналістам, які із задоволенням прийняли естафету.

Як свідчить С. Беннет, у 1919 р. американський видавець Е. В. Скриппс разом із відомим біологом У.Е. Ріттером почали проєкт, основним завданням якого були налагодження наукового спілкування та популяризація знань у США. Скриппс і Ріттер вважали, що громадяни повинні мати базові знання наукових принципів і цікавитися наукою хоча б на побутовому рівні (Bennet, 2013). Результатом співпраці видавця та вченого стало створення у 1921 р. неурядової організації Science Service, покликаної популяризувати науку за підтримки й участі провідних організацій, зокрема Американської асоціації сприйняття розвитку науки, Національної академії наук та Національного дослідницького центру. Science Service poзширила поле наукових новин, заклавши підгрунтя для наукового діалогу між ученими, журналістами та громадськістю, який триває і досі.

У XX ст. починається поступове розділення категорії «наукова журналістика» на власне «наукову» та «науково-популярну». У західній науковій думці це розмежування $є$ чітким і однозначним: «наукова журналістика» (англ. - science journalism) не лише презентує факти й події 3 різноманітних галузей наукової думки таким чином, щоб масова аудиторія зрозуміла, про що йдеться, а й допомагає розрізняти аргументовані та голослівні думки, викриває конфлікти інтересів 3 боку науковців, надає контекст, пояснюючи, яким чином нове знання вписується в уже наявний загал наукових напрацювань (Mehrabian, 2020). «Науково-популярна журналістика» (англ. - рориlar science journalism) ставить на меті популяризацію науки. Її завдання - привернути увагу широкої аудиторії до тих чи тих наукових напрямів, поширювати відомості про винаходи, формувати позитивний образ науковця тощо. Змістовний опис науково-популярної журналістки дає К. Молек-Козаковська: діяльність із науковопопулярного контентотворення - «це не стільки про перетворення текстових конструкцій та стилю в зрозуміліші ідіоми, скільки про виокремлення чи оздоблення наукової діяльності» $(2017$, р. 72). Цю тезу посилює Г. Майєрс, кажучи, що «тексти наукової журналістики стосуються науки, тоді як популяризаторські статті являють собою оповідь про природу» (Myers, 1990). Американських і європейських дослідників більше цікавить не розмежування зазначених категорій, а співіснування та взаємодія наукового світу з медійною сферою.

У 2018 р. Е. Данс опублікував у журналі Nature публіцистичний матеріал «On the record», присвячений питанням професійного спілкування між ученими та представниками 3MI, у якому презентував власне бачення сучасної наукової журналістики. У першому ж реченні міститься теза про важливість взаємодії вчених із медіа передусім для самих учених: «Інтерв'ю в ЗМІ можуть підвищити авторитет учених, якщо вони гарно підготовані та виправдають очікування» (Dance, 2018). Наступний абзац тексту Данса доцільно навести повністю, бо він найяскравіше демонструє сьогоднішню ситуацію в науковій журналістиці:

Чві Тек Лім у Національному університеті Сінгапура відповідає на телефонний дзвінок з ентузіазмом і деяким острахом. На тому кінці дроту - репортерка, що бажає почути про останні дослідження біомедичного інженера. Але чи точно вона опише наукову роботу? Чи віддасть вона належне його колегам? Лім із досвіду знає, що фінальна стаття або телепрограма буде не такою, як очікувалося. Але поки головні аспекти праці Ліма висвітлені правильно, він щасливий. «Вони роблять мені послугу, публікуючи наші дослідження», - зауважує вчений. (Dance, 2018)

I тут ми бачимо, що снобізм та закритість, які супроводжували наукову спільноту століттями й відмежовували ії від медійного сектора, зникли. Більше того, до науковців, які контактують зі 3MI, прихильні галузеві інвестори, донори та волонтери, які бажають брати участь у клінічних до слідах, публічним ученим легше працевлаштуватися, їх запрошують наукові установи, а не вони стукаються у двері потенційних роботодавців.

Розквіт наукової журналістики у світі припав на 1980-1990 рр., коли, наприклад, у США 95 газет мали постійні розділи, присвячені науці. 
Водночас активно інвестували в галузь $C N N, B B C$, Discovery, National Geographic, History Channel та інші медіа, розуміючи, що це інвестиції не для заробітку. Д.Брамфіл свідчив у 2009 р., що наприкінці XXст. «більшість видань готові були розвивати наукову тематику навіть собі в мінус, бо наука була необхідною» (Brumfiel, 2009). Ситуація почала змінюватися в епоху діджиталізації, коли наукова журналістика поступово перейшла в онлайн: спочатку в блогосферу, а потім у спеціалізовані нішеві видання.

Ефективність сьогоднішньої взаємодії між науковцями та журналістами залежить від багатьох факторів. Це й бажання налагоджувати комунікацію, й бачення обрисів власної аудиторії, й розуміння специфіки викладу наукової інформації масовій аудиторії тощо. Задля оптимізації цієї співпраці навіть створені ресурси, які містять настанови як для журналістів, так і для вчених щодо медійної активності. На ресурсі https://senseaboutscienceusa.org представлено «Медіагід для вченого», у якому викладено практичні поради науковцям щодо інтерв'ю із журналістами. Довідник складено за результатами опитування 218 наукових журналістів, він має три розділи: «Перед інтерв'ю», «Під час інтерв'ю» та «Після інтерв'ю». У ньому містяться поради і щодо алгоритмів комунікації зі 3MI, і щодо убезпечення науковців від необдуманих кроків та надмірного загравання із журналістами.

Продукти сучасної наукової журналістики сьогодні $є$ загальнодоступними, бо здебільшого представлені на мультимедійних онлайнових платформах із відкритим або частково обмеженим доступом. Однією з найвідоміших таких платформ $\epsilon$ австрало-американський кросмедійний проєкт Cosmos. Заснований 2004 р. Королівським інститутом Австралії (RiAus) як щоквартальний журнал з метою «викликати цікавість у “Науці про все” та зробити світ науки доступним для кожного» (https://cosmosmagazine.com/about-us), сьогодні цей мультимедійний комплекс за чотирма напрямами - журнал, сайт, передплатний діджитальний тижневик та освітній ресурс з індивідуальними уроками відповідно до шкільної програми 7-10 класів - взаємодіє з майже мільйонною аудиторією. Відштовхуючись у назві від космосу, видання, звісно, приділяє галузі достатньо уваги (рубрики «Астробіологія», «Астрономія», «Астрофізика», «Дослідження космосу» займають почесне місце у структурі і журналу, і сайту), але не зупиняється на ній. Достатньо детально представлені технологічні інновації, природничі науки та науки про Землю, історія, медицина, соціальні та поведінкові науки, біологія, фізика, хімія, математика, інженерія та культура. Таке тематичне різноманіття сприяє широкому охопленню аудиторії, а якісна журналістика та високопрофесійний дизайн і поліграфічної версії, і діджитальних проєктів сприяють тому, що Cosmos виборює перші місця в рейтингах наукових масових медіа світу.
Іншим проєктом наукової журналістики світового рівня є Popular Science - американський журнал із майже 150-річною історією. Різні довідники визначають Popular Science як науковопопулярний журнал, але для того, щоб пересвідчитись у належності видання саме до наукової, а не до науково-популярної журналістики, достатньо лише проаналізувати місію журналу:

Popular Science демістифікує світи науки й техніки з 1872 року. Ми пояснюємо внутрішню роботу телефону у вашій кишені, досліджуємо інновації, що змінюються у світі, і вивчаємо все - від чудес глибокого космосу до таємного життя основних продуктів, таких як хліб. Ми пропонуємо привабливий, доступний і всеосяжний погляд на нові технології та наукові досягнення. Щодня PopSci розкриває науку, що лежить в основі останніх новин, розбирає найновіші технології й цифрові тенденції та допомагає читачам жити розумніше, безпечніше і щасливіше завдяки розумним проєктам «зроби сам». <..> PopSci веде хроніку бурхливого світу інновацій для звичайних читачів, і це місія, що відповідає колишнім слоганам видання, таким як «Журнал усього нового» та «Майбутнє зараз». Із запуском popsci.com у 1999 році почався новий етап щоденних повідомлень про бурхливі світи персональних технологій і наукових досягнень. (https:// www.popsci.com/about-us)

Тематику публікації PopSci розвиває по 4 напрямах: наука, технології, DIY (англ. - do-ityourself - зроби сам) та огляди. Інших обмежень нема. Контент ресурсу становлять і повідомлення про новітні розробки астрофізиків, і огляди найкращих товарів дня, і повсякденні поради: «Чому немає більше екзопланет розміром із Землю? Астрономи вважають, що вони це зрозуміли», «Що спалах Yankees COVID означає для нас усіх», «Настала весна - час зібрати найкращий кошик для пікніка та максимально використати сезон», «Зробіть власну метеостанцію 3 перероблених матеріалів», «Тримайте свого собаку поруч і контролюйте найкращим собачим повідцем» та ін.

Американський журнал Discover заснований 1980 р. як науковий журнал для масової аудитоpiї. Редакційна формула видання передбачала більш глибокі тексти, аніж у PopSci, але не такі зарозумілі, як у Scientific American. Сьогодні читачам Discover i користувачам сайту https:// www.discovermagazine.com пропонують «захопливу пригоду, яка повідомляє про чарівні досягнення в науці, медицині, технологіях і факти про світ навколо нас. Ефектні фото й оригінальні та зрозумілі історії на складні теми поєднують звичайних людей із найвеличнішими ідеями та розумами в науці».

Журнал Scientific American не потребує додаткової презентації. Його майже 200-річна історія 
говорить сама за себе. 1845 р. його заснував Руфус М. Портер як тижневу газету із чотирьох сторінок, а сьогодні це транснаціональний кросмедійний проєкт 3 більш ніж 10-мільйонною аудиторією, яка взаємодіє з виданням через журнал і його міжнародні версії, вебсайт, інформаційні бюлетені та друковані й цифрові додатки. Серед авторів різножанрових мультимедійних публікацій не лише загальновідомі наукові журналісти, а й науковці, які адаптують розповіді про свої дослідження загальній аудиторії: «Авторитетні, захопливі статті, новини, думки і мультимедійні розповіді журналістів та авторівекспертів, зокрема більше 200 лауреатів Нобелевської премії, забезпечують необхідне охоплення, розуміння та висвітлення найважливіших подій на стику науки та суспільства» (https://www.scientificamerican.com/page/aboutscientific-american).

Український простір наукової журналістики представлено ресурсами «Куншт», «Спільне», «Світогляд», «Вселенная, пространство, время», «Наука и техника», «Країна знань» та деякими іншими. Виокремлюючи групу видань, які працюють у царині наукової журналістики, ми стикаємося 3 колізією, яка викликана сучасними нормативними документами. Справа в тому, що чинне законодавство вимагає від редакцій визначатися 3 типом ЗМІ відповідно до ДСТУ 3017:2015 «Інформація та документація. Видання. Основні види. Терміни та визначення понять». Цей документ пропонує декілька типів медіа, які розробляють наукову проблематику:

- наукове видання - видання, що містить результати теоретичних і (або) експериментальних досліджень, а також науково підготовлені до публікації пам'ятки культури та історичні документи 3 розгалуженим науково-довідковим апаратом;

- науково-популярне видання - видання, що містить відомості про дослідження в галузі науки, техніки, виробництва, культури, освіти, мистецтва тощо, які популяризують наукові знання, викладені в зрозумілій читачамнефахівцям формі;

- навчальне видання - видання, що містить систематизовані відомості наукового або прикладного характеру, викладені у зручній для вивчення й викладання формі. (КП, 2016, p. 9-10)

Коли ж мова йде про журнал, то дСТУ визначає науковий журнал як «журнал, який містить наукові публікації про теоретичні й прикладні дослідження». Науково-популярний журнал тлумачиться як «журнал, який містить публікації про основи наукових знань, а також досягнення в галузі науки, техніки, культури, мистецтва та практичної діяльності, викладені в зрозумілій читачам-нефахівцям формі» (КП, 2016, р. 19-20).
Таким чином, задля коректної ідентифікації редакції визначають себе як «науково-популярні видання» чи «науково-популярні журнали», якщо йдеться про друк. Більш детальної типологізації наявний ДСТУ не пропонує, а отже, в один ряд стають такі медіа, як «Колосок» і «Куншт». Ми пропонуємо розмежувати ці ЗМІ за принципом, запропонованим у гіпотезі. I враховуючи аудиторний та функціональний фактори, до наукової журналістики відносимо проєкти «Куншт», «Спільне», «Світогляд», «Вселенная, пространство, время», Science Ukraine, Alpha Centauri, «Наука и техника», «Країна знань», а до науково-популярної - «Вічного мандрівника», «Локальну історію», «Історію. Новий погляд», «Маловідому історію: далеке і близьке» та подібні. Результати аналізу тематики зазначених ресурсів, представлені в таблиці 1, переконують у правильності обраного підходу. Видання наукової журналістики структурують контент за науковими напрямами, науково-популярні медіа пропонують систему рубрик, притаманну звичайним масовим виданням.

Таблиця 1. Тематична складова інформаційної політики видань

\begin{tabular}{|l|l|}
\hline Назва проєкту & Основні тематичні рубрики \\
\hline Каукова журналістика
\end{tabular}

На жаль, популярність медіа, які працюють у царині наукової та науково-популярної журналістики, не велика. Найпопулярнішим серед аналізованих на сьогодні $є$ російськомовний ресурс https://naukatehnika.com («Наука и техника») iз 15-річною історією міжнародної діяльності, представництвами в Україні та Росії, за даними similarweb він має до 800 тис. відвідувань на місяць. Трафік https://thealphacentauri.net (Alpha Centauri) становить 150 тис. відвідувань, a https:// kunsht.com.ua («Куншт») — 25 тис. Для порівняння 
міська україномовна інтернет-газета The Village Україна має 1,5 млн відвідувань на місяць. Однак редакції видань не зупиняються і доволі ефективно пристосовуються до вимог онлайнового середовища. Так колись студентський журнал «Куншт», який створили два альтруїсти, перетворився сьогодні на повноцінний кросмедійний проєкт, який створює тексти у форматі наукової журналістики, подкасти та агрегує відеосюжети провідних медіа світу, надаючи україномовний текстовий супровід. На сайті функціонують блог і сувенірна крамничка з мерчем. Цікавим $є$ принцип фінансування проєкту. Усі матеріали розміщені у вільному доступі, але редакція пропонує користувачам долучитися до спільноти друзів «Куншт», оформивши один із трьох варіантів передплати. Залежно від обраного варіанту користувач отримує

доступ до закритої групи в Telegram та ексклюзивного контенту, науковий дайджест від Куншт щотижня, знижки на мерч та заходи Куншт, Epub-версії статей Куншт щомісяця, онлайн-трансляції заходів та участь у вебінарах «Куншт камера», можливість онлайн-зустрічі 3 командою, під час яких $\epsilon$ можливість пропонувати власні ідеї для статей та проєктів, вільний вхід на події закритого формату, іменного динозавра на окремому розділі сайту «Парк Кунштівського періоду», авторський значок «Друг науки», постер 3 авторськими ілюстраціями. (https://kunsht.com.ua/druzi)

$€$ також можливість надати виданню разову грошову допомогу.

Висновки. Таким чином, на нинішньому етапі розвитку медійного простору ми можемо говорити про гармонійну співпрацю наукової та науково-популярної журналістики. Кожен із цих видів працює 3 власним тематично-проблематичним простором, за власними правилами та законами, 3 власною аудиторією із залученням власних методів заради досягнення власної мети. I навіть за умови того, що обидва види мають справу з одним об'єктом - науковим знанням, продукт, який вони виробляють, $є$ категорично різним.

Висунута на початку дослідження гіпотеза про існування двох окремих комунікативістських категорій «наукова журналістика» та «науковопопулярна журналістика» підтвердилася отриманими результатами. Наукова журналістика, як 3'ясовано, продукує контент з орієнтацією на підготовлену аудиторію без зайвих застосувань методів інфотейнменту для поширення знань про події у світі науки. Науково-популярна журналістика, займаючись передусім популяризаці$є ю$ наукових знань і власне науки, використовує для цього весь наявний інструментарій залучення максимально широкої аудиторії: інфотейнмент, едьютейнмент, саєнстейнмент, ігровий контент тощо. Прояв цієї тенденції відбувається на змістовому (інформаційні приводи, герої, теми та ін.), структурному (архітектоніка текстів, їх жанрова палітра, формати подання, дизайн), платформному (використання потенціалу мультимедійної діджитальної системи, інтерактивні елементи, гіпертекстові зв'язки), етичному рівнях (принципи роботи з джерелами, інтерпретація та оприлюднення результатів). Узагальнюючи, запропонуємо таку диференціацію аналізованих медіа: «Куншт», «Спільне», «Світогляд», «Вселенная, пространство, время», Science Ukraine, Alpha Centauri, «Наука и техника», «Країна знань» $€$ каналами наукової журналістики, а «Вічний мандрівник», «Локальна історія», «Історія. Новий погляд», «Маловідома історія: далеке і близьке»науково-популярної.

\section{Покликання}

Державна наукова установа «Книжкова палата України імені Івана Федорова». (2016). Інформація та документація. Видання. Основні види. Терміни та визначення понять. ДП «УкрНДНЦ».

Литке, М. (2014). Научно-популярные и научно-познавательные журналы: проблема типологической классификации. Журналистский ежегодник, 3, 59-65.

Муравицкая, С. (2016). Научная журналистика: вопросы терминологии и тенденции современного развития. Человек и общество, 1, 56-57. https://doi.org/10.21661/r-113841

Пичугина, Т. (2006). Научная журналистика как исчезающий вид. https://sciencewriter.livejournal.com/9578.html.

Суворова, С. (2009). Журналистика научная и научно-популярная: особенности предметной области, функций, задач. Вестник Московского университета. Серия 10. Журналистика, 6, 14-23.

Allan, S. (2011). Introduction. Journalism, 12(7), 771-777. https://doi.org/10.1177/1464884911412688

Barel-Ben David Y., Garty E. S., \& Baram-Tsabari A. (2020). Can scientists fill the science journalism void? Online public engagement with science stories authored by scientists. PLoS ONE, 15(1). https://doi.org/10.1371/journal.pone.0222250

Bennet, C. D. (2013). Science Service and the origins of science journalism, 1919-1950 (Master's thesis, Iowa State University Capstones). https://lib.dr.iastate.edu/cgi/viewcontent.cgi? article $=4086 \&$ context $=$ etd

Brumfiel, G. (2009). Science journalism: Supplanting the old media? Nature, 458(7236), 274-277. https://doi.org/10.1038/458274a

Bucchi, M., \& Trench, B. (2014). Routledge handbook of public communication of science and technology (2nd ed.). Routledge. https://doi.org/10.4324/9780203483794

Dance, A. (2018). On the record. Nature, 562, 153-155. https://doi.org/10.1038/d41586-018-06871-7

Farberovic, 0. (2016). Science journalism as a key channel for promoting the achievements of modern science and technology: theoretical approaches. Ideas and innovations, 3(6), 98-106.

Mehrabian, A. (2020, November 9). On Good Science Journalism: Why It's Important and How to Produce It - ScienceBorealis.ca Blog. https://blog.scienceborealis.ca/on-good-sciencejournalism-why-its-important-and-how-to-produce-it.

Molek-Kozakowska, K. (2017). Communicating environmental science beyond academia: Stylistic patterns of newsworthiness in popular science journalism. Discourse \& Communication, 11(1), 69-88. https://doi.org/10.1177/1750481316683294

Myers, G. (1990). Writing Biology: Texts in the Social Construction of Scientific Knowledge. University of Wisconsin Press.

Nelkin, D. (1995). Selling science: How the press covers science and technology. W H Freeman \& Company.

Secko, D. M., Amend, E., \& Friday, T. (2013). Four models of science journalism. Journalism Practice, 7(1), 62-80. https://doi.org/ 10.1080/17512786.2012.691351

Tuten, H., \& Temesvari L. (2013). Popular science journalism: facilitating learning through peer review and communication of science news. Journal of College Science Teaching, 42(4), 4649 https://www.jstor.org/stable/43631920 


\section{References (translated and transliterated)}

Allan, S. (2011). Introduction. Journalism, 12(7), 771-777. https://doi.org/10.1177/1464884911412688

Barel-Ben David Y., Garty E. S., \& Baram-Tsabari A. (2020). Can scientists fill the science journalism void? Online public engagement with science stories authored by scientists. PLoS ONE, 15(1). https://doi.org/10.1371/journal.pone.0222250

Bennet, C. D. (2013). Science Service and the origins of science journalism, 1919-1950 (Master's thesis, Iowa State University Capstones). https://lib.driastate.edu/cgi/viewcontent.cgi? article $=4086 \&$ context $=$ etd

Brumfiel, G. (2009). Science journalism: Supplanting the old media? Nature, 458(7236), 274-277. https://doi.org/10.1038/458274a

Bucchi, M., \& Trench, B. (2014). Routledge handbook of public communication of science and technology (2nd ed.). Routledge. https://doi.org/10.4324/9780203483794

Dance, A. (2018). On the record. Nature, 562, 153-155. https://doi.org/10.1038/d41586-018-06871-7

Farberovic, 0. (2016). Science journalism as a key channel for promoting the achievements of modern science and technology: theoretical approaches. Ideas and innovations, 3(6), 98-106.

Litke, M. (2014). Nauchno-populyarnye i nauchno-poznavatelnye zhurnaly: problema tipologicheskoy klassifikatsii [Popular science and scientific and educational journals: the problem of typological classification]. Journalist Yearbook, 3, 59-65.

Mehrabian, A. (2020, November 9). On Good Science Journalism: Why It's Important and How to Produce It - ScienceBorealis.ca Blog. https://blog.scienceborealis.ca/on-good-sciencejournalism-why-its-important-and-how-to-produce-it.
Molek-Kozakowska, K. (2017). Communicating environmental science beyond academia: Stylistic patterns of newsworthiness in popular science journalism. Discourse \& Communication, 11(1), 69-88. https://doi.org/10.1177/1750481316683294

Muravitskaya, S. (2016). Scientific journalism: questions of terminology and tendencies of the modern development. Human and society, 1, 56-57. https://doi.org/10.21661/r-113841

Myers, G. (1990). Writing Biology: Texts in the Social Construction of Scientific Knowledge. University of Wisconsin Press.

Nelkin, D. (1995). Selling science: How the press covers science and technology. W H Freeman \& Company.

Pichugina, T. (2006). Nauchnaya zhurnalistika kak ischezayushchiy vid [Science journalism as an endangered species]. https://sciencewriter.livejournal.com/9578.html

Secko, D. M., Amend, E., \& Friday, T. (2013). Four models of science journalism. Journalism Practice, 7(1), 62-80. https://doi.org/ 10.1080/17512786.2012.691351

State Scientific Institution. "Ivan Fedorov Book Chamber of Ukraine". (2016). DSTU 3017: 2015 "Information and documentation. Edition. The main types. Terms and definitions". DP “UkrNDNC".

Suvorova, S. (2009). Zhurnalistika nauchnaya i nauchno-populyarnaya: osobennosti predmetnoy oblasti, funktsiy, zadach [Scientific and popular-scientific journalism: specifics of subject field, functions and goals]. Vestnik Moskovskogo universiteta. Seriya 10. Zhurnalistika, 6, 14-23.

Tuten, H., \& Temesvari L. (2013). Popular science journalism: facilitating learning through peer review and communication of science news. Journal of College Science Teaching, 42(4), 46-49. https://www.jstor.org/stable/43631920

Oksana Kyrylova

Oles Honchar Dnipro National University, Ukraine

\section{SCIENCE AND POPULAR SCIENCE JOURNALISM: DIFFICULTIES OF DEFINITION AND MEDIA TYPOLOGY}

This article is relevant because there is a need for scientific differentiation of two related categories of modern communication: science journalism and popular science journalism. There is no stable approach to this problem in the Ukrainian discourse, and the current normative documents force the editorial offices to determine the type of activity not according to the specifics of the media, but according to the list available, for example, in GOST. The object of the research were world and Ukrainian media specialized in scientific topics: "Cosmos", "Popular Science", "Discover", "Scientific American", "Kunsht", "Spilne", "Svitohliad", "Vselennaya, prostranstvo, vremya", "Science Ukraine", "Alpha Centauri", "Nauka i tekhnika", "Kraina znan", "Vichnyi mandrivnyk", "Lokalna istoriia", "Istoriia. Novyi pohliad", "Malovidoma istoriia: daleke i blyzke". At the same time, we analyzed digital practices (web resources), as well as traditional paper media (magazines). The subject of study is the peculiarities of the definition of scientific and popular science journalism and the complexity of the typology of the corresponding media. The main research method was comparative analysis, which, supported by discourse analysis, made it possible, firstly, to compare the existing scientific views on the categories of "scientific journalism" and "popular science journalism" and highlight the main features of each. Secondly, using these methods, an analysis of the world's leading resources specializing in science journalism was carried out and parallels with this type of Ukrainian media were made.

The result of the study is the typological differentiation of modern Ukrainian media resources. The study was based on the hypothesis that the characteristics of the audience and the functional specificity of the resource are decisive factors in terms of differentiation of the media as science and popular science. According to it, those media that are oriented towards advanced users, focus on the latest achievements of science and technology and restrained use online opportunities, almost without resorting to methods of edutainment and sciencetainment, we attribute to the channels of science journalism. The media that combine directions for the mass user, focus on the educational component and different popular pseudo-scientific topics with prolonged potential relevance, we refer to popular science journalism. Taking into audience and functional factors we include following projects of science journalism: "Kunsht", "Spilne", "Svitohliad", "Vselennaya, prostranstvo, vremya", "Science Ukraine", "Alpha Centauri", "Nauka i tekhnika", "Kraina znan". "Vichnyi mandrivnyk", "Lokalna istoriia", "Istoriia. Novyi pohliad", "Malovidoma istoriia: daleke i blyzke" we refer to popular science journalism.

Keywords: science journalism; popular science journalism; scientific media discourse. 